\section{The influence of the technology-organization- environment framework and strategic orientation on cloud computing use, enterprise mobility, and performance}

\author{
Winnie $\mathrm{Ng}$ Picoto $^{1}$ \\ Nuno Fernandes Crespo ${ }^{1}$ \\ Filipa Kahn Carvalho ${ }^{2}$ (ID
}

\begin{abstract}
Purpose - The objective of this paper is threefold. It aims i) to identify the antecedents of the use of cloud computing, ii) to understand the effect of the use of cloud computing together with strategic orientations on enterprise mobility, and iii) to comprehend the effect of the use of cloud computing and enterprise mobility on organizational performance.
\end{abstract}

Theoretical framework - This paper builds on the technology-organizationenvironment framework and on previous studies of enterprise mobility to propose a comprehensive research model to analyze cloud computing adoption and usage. In addition, the strategic orientation framework is applied as support for a reorientation of strategy toward enterprise mobility.

Design/methodology/approach - We developed a questionnaire and collected data from 137 Portuguese organizations that are using cloud computing. The data collected were then analyzed through partial least squares (PLS-SEM).

Findings - The results indicate that convenience, compatibility, and organizational confidence are significant antecedents of the use of cloud computing. Moreover, cloud computing usage, innovation orientation, and entrepreneurial orientation have a positive effect on enterprise mobility.

Research Practical \& Social implications - This study contributes to this field of research, since it contains the first research model to integrate cloud computing usage, enterprise mobility and strategic orientation, confirming the relationship between those constructs. As practical implications, the results show that greater usage of both cloud computing and organizational mobility is important to achieve superior levels of organizational performance.

Originality/value - This paper proposes an integrative model to analyze the use of cloud computing by organizations, in terms of its antecedents and impacts on firm performance and enterprise mobility.

Keywords - cloud computing use, organizational mobility, innovation orientation, entrepreneurial orientation, TOE framework.

\footnotetext{
1. CSGIADVANCE, ISEG - Lisbon School of Economics \& Management, Universidade de Lisboa, Lisbon, Portugal.

2. ISEG - Lisbon School of Economics \& Management, Universidade de Lisboa, Lisbon, Portugal.
}

\section{How to cite:}

Picoto, W., Crespo, N., Carvalho, F. (2021). The influence of technologyorganization-environment framework and strategic orientation of cloud computing use, enterprise mobility, and performance. Revista Brasileira de Gestão de Negócios, 22(1), firstpage-lastpage.
278

Received on:

07/25/2019

Approved on:

$11 / 10 / 2020$

Responsible Editor:

Prof. Dr. João Maurício Boaventura

\section{Evaluation process:}

Double Blind Review

\section{Reviewers:}

Cristina Dai Prá Martens; Judith Cavazos-Arroyo.

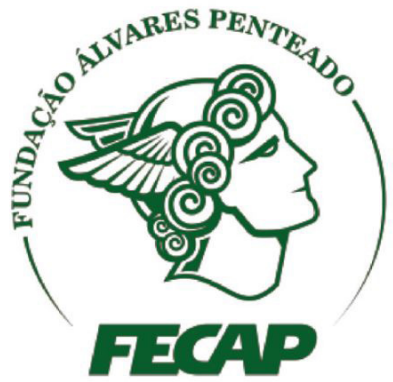

Revista Brasileira de Gestáo de Negócios

https://doi.org/10.7819/rbgn.v23i2.4105 
The influence of the technology-organization-environment framework and strategic orientation on cloud computing use, enterprise mobility, and performance

\section{Introduction}

Developments in information technologies (IT) and network infrastructures have changed the way physical organizations and individuals use information systems applications and resources. Additionally, mobile devices with their increasing computer capabilities are important resources in helping organizations become mobile. This is part of the so-called "digital transformation" that has been challenging organizations to use information systems and technologies to innovate in their products and services as well as in the processes and models of their businesses (Hess, Matt, Benlian, \& Wiesböck, 2016). Cloud computing enhances access to a wide range of digital services and infrastructure to implement digital transformation $(\mathrm{Vu}$, Hartley, \& Kankanhalli, 2020).

The use of web-based applications such as Dropbox, Facebook, Gmail, and Google Docs increases awareness of the concept of "cloud computing" as these services are used extensively for both professional and personal purposes. Cloud computing is the natural evolution of IT management and provides the flexibility and agility needed to gain competitive advantages, thus leading to a new computing paradigm. Cloud computing is a growing phenomenon. In fact, according to the Synergy Research Group (2019), investment in data-center hardware and software grew by $17 \%$ in 2018 . According to that same source, "cloud service revenues continue to grow by almost $50 \%$ per year, enterprise SaaS revenues are growing by $30 \%$, search/social networking revenues are growing by almost 25\%, and e-commerce revenues are growing by over $30 \%$, all of which are helping to drive big increases in spending on public cloud infrastructure" (Synergy Research Group, 2019, p.1).

According to Low, Chen, and Wu (2011, p. 1007), cloud computing can be defined as "a kind of computing application service that is like email, office software, and enterprise resource planning (ERP) and uses ubiquitous resources that can be shared by the business employee or trading partners." This ability allows firms to locate organizational information resources on servers elsewhere that are accessible through the internet. As such, cloud computing supports the ubiquitous accessibility of information resources, enabling the use of mobile business applications. Therefore, organizations that adopt cloud computing services are more likely to use mobile applications (Nkosi \& Mekuria, 2010). Cloud computing is an enabler of enterprise mobility.
There are a number of studies (e.g. Alshamaila, Papagiannidis, \& Li, 2013; Gangwar, Date, \& Ramaswamy, 2015; Lian, Yen, \& Wang, 2014; Low et al., 2011; Nkhoma \& Dang, 2013; Priyadarshinee, Raut, Jha, \& Gardas, 2017; Senyo, Addae, \& Boateng, 2018; Senyo, Effah, \& Addae, 2016) that identify the antecedents of adopting cloud computing, some of which are based on the technology-organization-environment (TOE) framework (Tornatzky \& Fleischer, 1990). However, no studies have examined whether the adoption of cloud computing plays a role in enabling enterprise mobility. The present research aims to fill this gap in the literature. Additionally, as enterprise mobility is a strategic option, we also build on the strategic orientation theory to understand the effects of innovational and entrepreneurial orientations on enterprise mobility. Thus, the following research questions guide the development of the present study: (i) what are the antecedents of the use of cloud computing?, (ii) what is the effect of using cloud computing together with innovational and entrepreneurial orientations on enterprise mobility?, and (iii) what is the effect of enterprise mobility on organizational performance?

The remainder of this paper is structured as follows. The next section presents the literature review on the definitions and adoption of cloud computing, enterprise mobility, and the TOE framework. The third section presents the conceptual model and the research hypotheses. The fourth section describes the method applied in this work, and the following section presents the data analysis and results. The last section presents the concluding remarks, limitations, and further research related to this work.

\section{Literature Review}

\section{I Adopting and using cloud computing}

In the year 2000, Salesforce, a pioneering company in cloud computing, released web-based software for interacting with its customers, which replaced physical products with virtual services offered as a software as a service (SaaS). In 2006, Amazon launched Amazon Web Services, and Google offered a free online service for email (Gmail) with unlimited storage capacity. In fact, "cloud computing is a new paradigm shift in which including computing resource services, soft applications of distributed systems and data storage" is the standard (Low et al., 2011, p. 1007). Furthermore, cloud computing can be 
defined as a service model based on the internet in which information, storage capacity, and software resources are shared through computers and other information technology devices. Besides the change in IT business models (Sharma, Gupta, \& Acharya, 2020), these services allow users to access information from different devices and different locations, allowing for greater mobility and flexibility (Vu et al., 2020) by giving each user the option to choose how to use and manage the resources available in the cloud. The data and applications needed for accessing cloud services are not stored on the user's devices but on remote servers managed by the cloud computing vendor (Chandran \& Angepat, 2010). Cloud computing can also be considered a pool of scalable resources from which an infrastructure can host end-customer applications that are billed according to usage (Sharma et al., 2020). Iyer and Henderson (2010) argue that cloud computing should be defined in terms of the services offered (infrastructure level, platform as a service level, application level, collaboration level, and service level) and in terms of the main types of cloud computing models (public, private, community, and hybrid clouds).

The concept of cloud computing comprises a fairly comprehensive set of different services (such as emails, online advertising, website development platforms, word processing tools, data storage, management, and sharing) available on the internet (Cusumano, 2010). Importantly, the use of this technology by organizations turns CAPEX (capital expenditure) into OPEX (operational expenditure), which transforms the investments needed into operating expenses, allowing investments to be made in the core business of companies (Armbrust et al., 2010). With its "pay as you use" model, cloud computing is a scalable solution that does not require high levels of investment (Sharma et al., 2020).

While several studies present different reasons why organizations adopt cloud computing, the benefits of adopting it are not yet clear, and it is important to understand these factors (Sharma et al., 2020). One major goal of cloud computing is to reduce IT costs (Zhang, 2012) and allow organizations to better access IT services and infrastructure (Vu et al., 2020). Lin and Chen (2012) develop a study based on 19 interviews with IT professionals in order to understand the main concerns and benefits related to the adoption of cloud computing. They find that many vendors claim that computational power and cost reductions are the main benefits of cloud computing. However, IT managers are concerned about the cloud's compatibility with existing companies' policies, information systems, and business needs and are unsure about the security and standardization that cloud services may provide. Additionally, Low et al. (2011) find that relative advantage, top management support, organizational size, competitive pressure, and pressure from partners are drivers of the adoption of cloud computing. In another study, Nkhoma and Dang (2013) claim that the drivers for adopting cloud computing are business scalability, cost, flexibility, and access to industry expertise. Sharma et al. (2020) conduct a mixed-method study and conclude that time to market, IT service costs, financial losses, and competitive pressure are among the most important factors that influence the adoption of cloud computing.

Companies should adopt cloud solutions gradually by increasing the number of applications and services over time (Low et al., 2011). Furthermore, in order to accomplish the benefits of adopting cloud computing, management tools must be integrated (Applegate, 2006). The adoption of cloud computing may involve highly complex tasks and may lead to organizational changes (Serrano, Caldeira, \& Guerreiro, 2004); its success depends not only on technical factors, but also on the characteristics of the organization (Behrend, Wiebe, London, \& Johnson, 2011).

\subsection{Enterprise mobility}

Advancements in mobile technologies have made mobile business very appealing for both personal and professional purposes. The high levels of adoption have pressured organizations to offer their services through mobile technologies. To create value from adopting mobile technology, the definition of organizational strategies must include the transformation of traditional processes into mobile business processes. Changes not only occur in the technological infrastructure but also in business processes and human resources (Sørensen, 2011).

In the present paper we adapt the concept of a mobile enterprise to enterprise mobility, as proposed by Stieglitz and Brockmann (2012, p. 190), who define a "mobile enterprise as an organization that provides access to enterprise systems via wireless mobile devices such as smartphones or tablets. Employees are able to use mobile devices to interact with colleagues or customers, to access all needed information, as well as to share information." Therefore, enterprise mobility supports and executes an organization's operations regardless of the geographical 
The influence of the technology-organization-environment framework and strategic orientation on cloud computing use, enterprise mobility, and performance

position of the employees (Barnes, 2003). To achieve the expected benefits from mobile business, such as increasing employees' productivity, increasing sales, and reducing procurement costs (Picoto, Bélanger, \& Palmados-Reis, 2013), a well-designed corporate-wide strategy needs to be developed to attend to the technological and organizational aspects of mobile technologies in order to achieve enterprise mobility.

Cloud computing is "an unlimited resource that can be accessed anytime and anywhere in the world" (Nkosi \& Mekuria, 2010, p. 629), allowing organizations to leverage its ubiquitous characteristics to implement mobile business processes. Repschlaeger, Erek, and Zarnekow (2013) have also identified mobility as a key factor in cloud computing, since it may increase the organizational capacity to implement mobile business. Additionally, the availability of information "every time and everywhere" allows employees to work independently away from a fixed workspace (Patel, 2014; Stieglitz \& Brockmann, 2012).

\subsection{Strategic orientation}

The way organizations deal with technology, particularly in terms of use and adoption, is related to their strategic orientation. Strategic orientation refers to the organization's ideology that is inherent to its way of doing business. This ideology translates into specific values and beliefs as well as in the paths that the organization adopts to organize its infrastructure and behavior in a way that leads to superior performance (Gatignon \& Xuereb, 1997; Narver \& Slater, 1990; Yu, $\mathrm{Li}, \mathrm{Li}, \mathrm{Zhao}, \&$ Zhao, 2018). The strategic orientation of organizations operates as a mechanism that helps to deal with competitive forces and respond to market needs in order to sustain their competitive advantages. Therefore, strategic orientation is an organizational philosophy that may support innovation or technological adoption (Han, Kim, \& Srivastava, 1998; Julien \& Raymond, 1994; Wang \& Qualls, 2007; Yu et al., 2018). It works as a spark of rationality for organizations.

There are many studies that support the relevance of strategic orientation as a determinant of organizational innovation (Frambach \& Schillewaert, 2002; Pérez-Luño, Wiklund, \& Cabrera, 2011; Salavou, Baltas, \& Lioukas, 2004; Zhou, Yim, \& Tse, 2005b) or technology adoption (Chan, Huff, Barclay, \& Copeland, 1997; Kauffman, Ma, \& Yu, 2018; Wang \& Qualls,
2007). They highlight some strategic orientation types as being more prone to the adoption of organizational innovation, specifically entrepreneurial and innovation orientations (Yu et al., 2018; Zhou et al., 2005b). Even though these strategic orientations partly share a focus on innovation, they are clearly different concepts (Jones \& Rowley, 2011).

Entrepreneurial orientation captures particular entrepreneurial aspects of decision-making styles, methods, and practices (Lumpkin \& Dess, 1996) and can be characterized by innovativeness, proactiveness, and risktaking (Covin \& Slevin, 1991; Miller \& Friesen, 1983). Therefore, this strategic orientation entails a commitment to innovate, renew market offers, and take risks; to try new and uncertain products, services, or markets; and to be more proactive than rivals when embracing new business opportunities (Wiklund \& Shepherd, 2005). By presenting these types of behaviors, the organization's processes and structures will be organized in order to pursue new market opportunities, to accomplish strategic objectives (Wang, 2008), and to innovate in existing operations (Zhou et al., 2005b). In line with these arguments, several studies find that an entrepreneurial orientation is critical to accepting, adopting, and using new technologies and new organizational innovations (Lal, 1999; Pérez-Luño et al., 2011; Putniņš \& Sauka, 2019; Zhai et al., 2018).

Similarly, innovation orientation can be defined as a multidimensional composition that comprises a learning philosophy, a strategic direction, and beliefs shared across all the organization's functions that "guide and direct all organizational strategies and actions, including those embedded in the formal and informal systems, behaviors, competencies, and processes of the firm to promote innovative thinking and facilitate successful development, evolution, and execution of innovations" (Siguaw, Simpson, \& Enz, 2006, p. 560). Since the main driver of this strategic orientation is openness to innovation (Chou, Chen, \& Liu, 2017), organizations with a greater innovation orientation are more prone to adopting new technologies, resources, skills, administrative systems, and new organizational innovations (Hurley \& Hult, 1998), such as the ones related to mobile technologies (Ergün \& Kuşcu, 2013; Moon \& Norris, 2005; Wang \& Cheung, 2004) and cloud computing (Ali, Warren, \& Mathiassen, 2017; Chou et al., 2017). 


\subsection{Technology-organization- environment (TOE) framework}

In order to describe the factors that may affect the adoption of technological innovations by organizations, Tornatzky and Fleischer (1990) developed the technologyorganization-environment (TOE) framework. This framework holds that there are three contexts or dimensions that influence decision-making on adopting new technologies from the organizational perspective: technological, organizational, and environmental. The technological context is the analyzation of the technological characteristics of the innovation, which in this study is cloud computing, the technologies already in use in the organization (internal), and the technologies that are available to the company (external) but have not been implemented yet. This context comprises, for example, a lack of interoperability [defined as the difficulties in integrating cloud-computing with the organization's systems (Teo, Ranganathan, \& Dhaliwal, 2006)], the compatibility of cloud computing with the existing technological structure in the organization, the perception that it is consistent with the organization's internal resources (Sharma et al., 2020), and its convenience (Tornatzky \& Fleischer, 1990). The organizational context includes the characteristics of the organization, such as confidence (regarding its belief in being able to adopt the technological innovation) and IT know-how, which is defined as the IT expertise and necessary knowledge to effectively use cloud computing (Shen, Huang, Chu, \& Hsu, 2010). All these factors may influence the acceptance of an innovation (Tornatzky \& Fleischer, 1990). The environmental context describes the environment in which the company conducts its affairs, which are influenced by the characteristics of the industry, the competitive pressure [competitors force the organization to adopt cloud computing (Sharma et al., 2020)], and trust, which is defined as the vulnerability to suppliers (Priyadarshinee et al., 2017).

The adoption of new technological innovations requires the existence of a technology portfolio, a defined organizational structure, and an environmental strategy (Swanson, 1994). Several authors have used the TOE framework to explain aspects of the adoption of technology by organizations, such as the influence of TOE factors on the use of e-business (Zhu \& Kraemer, 2005), the effect of factors on the adoption of open systems (Chau \& Tam, 1997), assessments of the value of e-business at the firm level (Lin \& Lin, 2008), and the factors that influence the use of mobile business (Picoto, Bélanger, \& Palma-DosReis, 2014). There are many factors that may influence the adoption of cloud computing, and in this study we classify some of them as technological, organizational, and environmental (Low et al., 2011; Sharma et al., 2020). We build on the aforementioned studies to develop a comprehensive model for analyzing the use of cloud computing instead of its adoption. We add the enterprise mobility and performance constructs to assess whether higher levels of cloud computing contribute to supporting enterprise mobility and to enhancing the performance of an organization. Additionally, as the advantages of cloud computing are more significant in new companies (Lin \& Chen, 2012; Wang, Ren, Wang, \& Ieee, 2011), we add strategic orientation to the TOE framework, which can also promote the use of new technology.

\section{Conceptual Model and Hypotheses}

This study focuses on the factors that may influence the use of cloud computing services by organizations in Portugal. We developed a research model, as shown in Figure 1, to understand the effect of each factor on the use of cloud computing. For this, we build on the studies about cloud computing and the TOE framework to consider a set of antecedent constructs that are framed within each TOE dimension. As the research indicates that cloud computing enables enterprise mobility, we extend the model by including the enterprise mobility construct. As enterprise mobility can be a strategic choice, we also include strategy orientation to develop a model that better explains enterprise mobility. Further, we assess the effects of using cloud computing and enterprise mobility on company performance.

\section{I Technological factors}

Cloud computing's interoperability relates to its ability to integrate information and technologies available from the cloud into internal organizational systems and infrastructure (Repschlaeger et al., 2013). The studies on innovation adoption have identified the lack of interoperability as a major inhibitor of technology adoption (Teo et al., 2006). In fact, not being able to adequately integrate cloud computing applications, hardware, and platforms into the existing organizational technology infrastructure may affect the use of cloud computing. Following this reasoning, we propose the first hypothesis: 
The influence of the technology-organization-environment framework and strategic orientation on cloud computing use, enterprise mobility, and performance

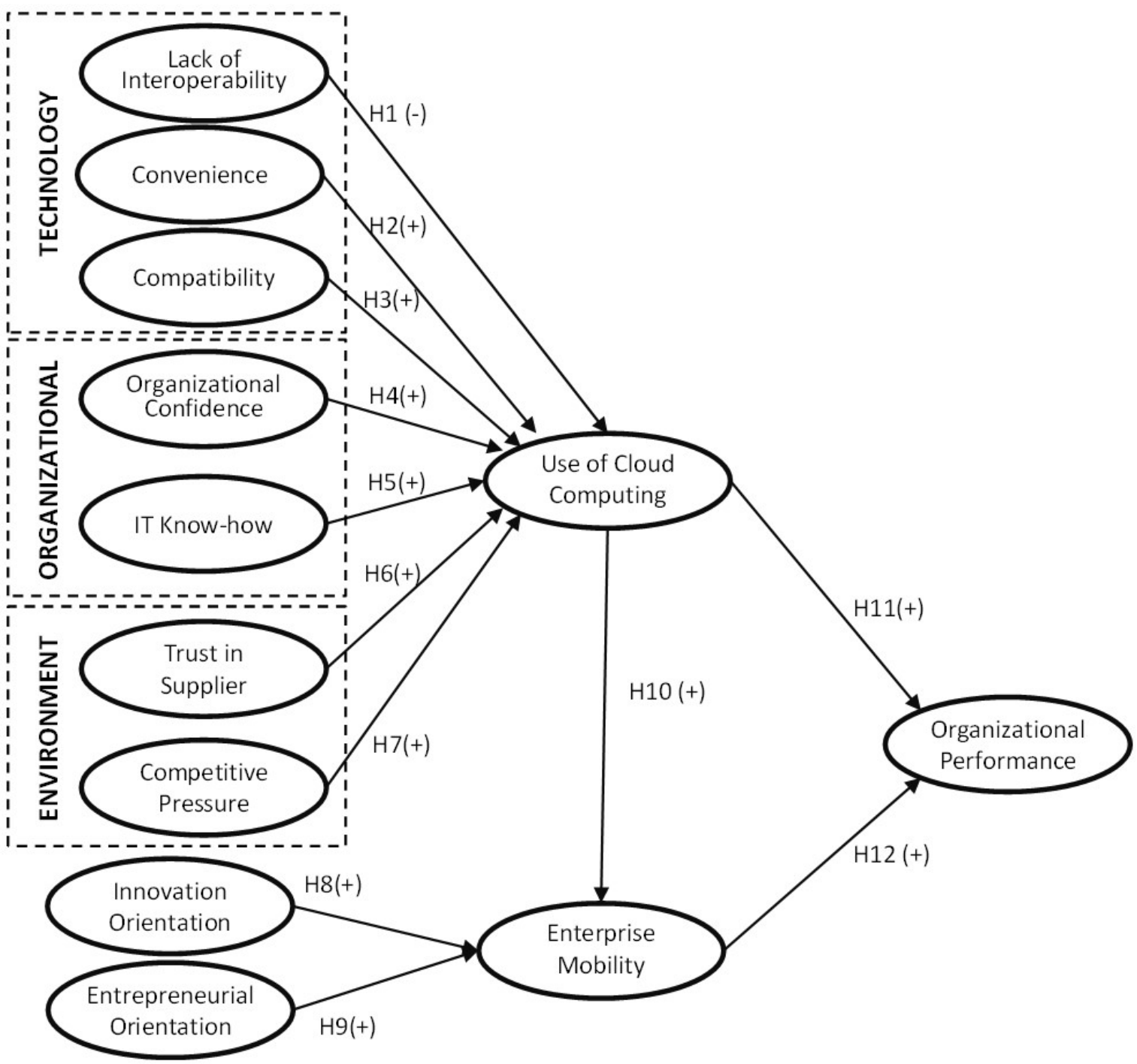

Figure 1. Conceptual Model for Cloud Computing Use

H1: A lack of interoperability will negatively influence the use of cloud computing.

Convenience is a situational criterion for choices of actions while searching for information, including the choice of the source of information, the degree of satisfaction with the source, and the ease of its use (Connaway, Dickey, \& Radford, 2011). This concept is based on the rational choice theory (Green, 2002), which posits that individuals act in their own interests and according to their own preferences, values, and utilities (Friedman \& Hechter, 1988). Gupta et al. (2013) find that convenience is among the main factors that affect the adoption of cloud computing by small and medium-sized organizations. This effect relates to the fact that increasing the use of mobile devices to perform business activities, while moving applications and information resources into the cloud, leverages this unique value proposition of mobile business (Picoto et al., 2013). Thus, we propose the following hypothesis:

H2: Convenience will positively influence the use of cloud computing.

The concept of compatibility refers to the level at which innovation is perceived as consistent with internal organizational processes and information systems (Rogers, 2003). Studies have considered this factor to be an important driver for technology adoption (Tornatzky $\&$ Klein, 1982). An organization's internal environment encompasses its structures, values, experiences, and culture as well as the processes and strategy of the business. Studies on the adoption of web technology find that the first organizations to adopt technologies put more emphasis on the perceived benefits and compatibility with existing standards in the organization (Beatty, Shim, \& Jones, 2001). Studies on the adoption of cloud 
computing have also considered the effect of this variable in their analyses (Oliveira, Thomas, \& Espadanal, 2014; Sharma et al., 2020). However, the results are not always consistent, as Lian et al. (2014), Oliveira et al. (2014), and Alshamaila et al. (2013) found compatibility to be a significant determinant of the adoption of cloud computing, while Low et al. (2011) were not able to confirm this relationship. In line with the studies on the adoption of technology and cloud computing, we propose the following hypothesis:

H3: Compatibility will positively influence the use of cloud computing.

\subsection{Organizational factors}

At the organization level, confidence is the degree to which an organization is confident enough to adopt a new idea (Rogers, 2003). This confidence represents the organization's belief that it possess the necessary skills and resources to effectively adopt and successfully use cloud computing (Vu et al., 2020). Shen, Huang, Chu, and Hsu (2010) argue that when employees feel certain levels of anxiety related to a specific technology, they are not comfortable with their abilities to master that technology. In contrast, confidence regarding a cloud computing technology may positively influence its use (Gupta et al., 2013; Low et al., 2011). In fact, if the organization has a positive attitude towards the new technology and thinks that its use is beneficial, then it is more likely to intensively use cloud computing (Gupta et al., 2013; Khayer, Talukder, Bao, \& Hossain, 2020; Priyadarshinee et al., 2017). We therefore present the following hypothesis:

H4: Organizational confidence will positively influence the use of cloud computing.

IT know-how is the result of the organizational information technology infrastructure and the IT professionals that work in that infrastructure. Organizations see cloud computing as an IT innovation (Lian et al., 2014). If an organization already has internal IT competences (i.e., human resources and IT infrastructure), then it may develop a more positive attitude towards the new innovation. In short, if the IT personnel have the necessary skills to adopt cloud computing, the organization might be more confident in engaging in the process (Dincă, Dima, \& Rozsa, 2019; Lian et al., 2014). Additionally, the skills and knowledge of employees are a source of competitive advantages (Hall \& Khan, 2002) and are a major enabler of IT adoption (Caselli \& Coleman, 2001). In fact, IT staff are more able to quickly identify the value of new IT innovations and seek to apply them in order to increase productivity (Nonaka, Toyama, \& Konno, 2000). Based on these arguments, we present the following hypothesis:

H5: The existence of IT know-how will positively influence the use of cloud computing.

\subsection{Environmental factors}

Given the nature of cloud computing services, confidence and trust in the supplier is crucial for organizations to engage in their adoption (Lin \& Chen, 2012). Trust results from confidence in the other party and that the execution of an action will result in positive activities (Anderson \& Narus, 1990). In fact, the research has found that stronger organizational relationships with providers are an important determinant of the adoption of cloud computing (Dincă et al., 2019). The reliability, security, and privacy of cloud services are major concerns regarding this technology; so if the provider is trustworthy, organizations are more likely to overcome this concern. In fact, Gupta et al. (2013, p. 872) state that "the forthcoming usage and adoption of cloud by SMEs (small and medium enterprises) is very much dependent on how the cloud providers are able to build the trust, faith, confidence, and reliability of their services for SMEs." Based on these arguments, we present the following hypothesis:

H6: Trust in a provider will positively influence the use of cloud computing.

Competitive pressure is the level at which existing competition within a market affects an organization and is an important factor according to some of the studies on the adoption of cloud computing (Dincă et al., 2019; Lian et al., 2014; Low et al., 2011). In fact, if an organization experiences a higher level of competitive pressure, this pressure motivates the organization to implement new technologies to be able to reduce costs or gain competitive advantages (Lian et al., 2014). In order to achieve the benefits expected from the use of cloud computing, organizations that experience higher levels of competitive pressure are more likely to engage in the adoption and implementation of this innovation. Thus, we present the following hypothesis:

H7: Competitive pressure will positively influence the use of cloud computing. 
The influence of the technology-organization-environment framework and strategic orientation on cloud computing use, enterprise mobility, and performance

\subsection{Strategic orientations}

Some researchers argue that cloud computing has a major advantage in terms of cost reductions, which is particularly relevant for SMEs and start-ups due to their size (Gupta et al., 2013). On the other hand, the research identifies entrepreneurialism as a determinant of IT adoption (Lal, 1999). Entrepreneurial firms are more likely to adopt innovation (Pérez-Luño et al., 2011) and show a high technology orientation (Hakala \& Kohtamäki, 2010). Therefore, organizations that show a proactive, innovative, and risk-taking attitude are more likely to implement mobile technologies and applications to develop their organizational strategy, which leads to enterprise mobility, thus creating value from mobile technologies (Putniņš \& Sauka, 2019; Zhai et al., 2018). In line with this reasoning, we present the following hypothesis:

H8: An entrepreneurial orientation will positively influence enterprise mobility.

Along the same vein, the innovation orientation of firms has relevant implications for understanding the adoption of technologies as well as innovative ways of doing business that are based on mobile technologies (Ali et al., 2017; Wang \& Cheung, 2004). Additionally, Dincă et al. (2019) find that managers' innovation capability is an important antecedent for their adoption of cloud computing. When they promote innovation, organizations are not only concerned with the invention of innovative products and services, but also with new technologies, production, processes, and business practices (Amit $\&$ Zott, 2001; Wang \& Cheung, 2004). Hence, a strategic orientation based on innovation is required to address organizational issues such as digital transformation or enterprise mobility (Ali et al., 2017; Chou et al., 2017; Ergün \& Kuşcu, 2013), in order to achieve high overall performance (Stieglitz \& Brockmann, 2012). Based on these arguments, we propose the following hypothesis:

H9: An innovation orientation will positively influence enterprise mobility.

\subsection{Effect on performance}

The ubiquitous access to and availability of cloud computing infrastructures, platforms, and applications support the implementation and use of mobile technologies and applications (Nkosi \& Mekuria, 2010). Furthermore, cloud computing may be used to overcome some of the limitations in mobile devices that are used as service platforms in an organizational context (Nkosi \& Mekuria,
2010). In fact, organizations that are heavy adopters of cloud computing for different purposes are more likely to transform their business processes and systems to adopt mobile applications (Marston, Li, Bandyopadhyay, Zhang, $\&$ Ghalsasi, 2011). In line with that reasoning, we put forward the following hypothesis:

H10: The use of cloud computing will positively influence enterprise mobility.

The active adoption or use of a technology resource by an organization to develop its core competencies will enhance its performance (Ilmudeen, Bao, \& Alharbi, 2019; Khayer et al., 2020). The research supports the positive effect of the adoption and use of specific IT- related technologies on firm performance (Chan \& Chong, 2012; Khayer et al., 2020).

According to Marston et al. (2011), organizations adopt cloud computing expecting to achieve cost efficiency, increase flexibility, and have greater access to IT resources. When organizations access IT resources held by a third party remotely, they reduce their own costs of owned IT infrastructure and its maintenance and obsolescence (Khayer et al., 2020). Furthermore, Marston et al. (2011) also argue that cloud computing provides not only increased IT efficiency but also greater business agility, which should be seen as leverage to achieve competitive advantages. Following this line of reasoning, the upmost objective of organizations engaging in cloud computing is to enhance their performance. Thus, we develop the following hypothesis:

H11: The use of cloud computing will positively influence organizational performance.

When organizations move towards mobility, one of the main objectives is to achieve higher business value and thus superior performance (Picoto et al., 2013; Stieglitz $\&$ Brockmann, 2012). The adoption of technologies that increase enterprise mobility influences both individual employee mobility and organizational mobility (Wang, Chen, Zhu, \& Lin, 2018). By using mobile IT, employees can change their work practices and improve their task and job performances (Chung, Lee, \& Kim, 2014; Tam \& Oliveira, 2017). On the other hand, organizations can change their business models, as they progressively develop and implement an organization-wide mobile strategy as part of their global business strategy, with the main purpose of increasing their global performance (Wang et al., 2018). There is some evidence that enterprise mobility has a positive effect on organizations' performance (Wang et al., 2018). Therefore, we propose the following hypothesis: 
H12: Enterprise mobility will positively influence organizational performance.

\section{Method}

\section{I Sample and data collection}

To achieve the research objectives proposed in this study, the empirical data used to test the hypotheses of the conceptual model were obtained by conducting a survey. This survey was sent to several companies that had already adopted cloud computing. The initial population of the study was selected from the business customer database of a major Portuguese telecommunications company. The selection took into account whether those business customers had already adopted cloud computing solutions from that telecommunications company.

An email requesting participation in the study was sent to the head of each organization (owner, manager, $\mathrm{CEO}$ ) or to the person responsible for the information technology area (IT director or head of IT) as both types of respondents are more likely to be involved in the decision to adopt cloud solutions in the organization. A link to the web survey was included in the email. The questionnaire was pre-tested on three companies with the aim of identifying potential difficulties in its interpretation. Only small changes resulted from this process. The final survey was sent to 993 companies by email. To increase the response rate, three follow-up emails were sent. We gathered a total of 137 complete responses in the two-month period, which corresponded to a $14 \%$ response rate. Table 1 presents the characterization of the sample in terms of the number of employees, number of IT employees, respondent's position and educational level, and the sector to which the firm belongs.

\subsection{Measures}

The variables that are incorporated into the model are measured by using or adapting validated instruments from the literature regarding the adoption of technological innovations and cloud computing. All the variables are measured using multi-item scales, by applying a seven-point Likert-type scale, usually ranging from " $1=$ strongly disagree" to " $7=$ strongly agree." The unit of analysis is the company for all the variables included in the model. The appendix provides information regarding the operationalization of all the variables as well as their reliability and validity assessments.
The variable regarding the lack of interoperability was measured using a three-item scale adapted from Teo et al. (2006). The variables of convenience (three items), organizational confidence (four items), IT knowhow (five items), and trust in the supplier (six items) were all adapted from Shen et al. (2010). Even though the original scales were related to mobile banking services, they were adapted for cloud computing services. The variable regarding compatibility was measured by using a threeitem scale adapted from $\mathrm{Zhu}$, Dong, $\mathrm{Xu}$, and Kraemer (2006), while the competitive pressure variable was measured by using a three-item scale from Wang, Wang, and Yang (2010). The entrepreneurial orientation variable was measured on a second order scale with a total of nine items organized in three different dimensions (three items each): proactiveness, innovativeness, and risk-taking. This scale was adapted from Lumpkin and Dess (2001). The innovation orientation variable was measured using a three-item scale from Zhou, Gao, Yang, and Zhou (2005a). The enterprise mobility and use of cloud computing variables were both measured by a set of four and three items, respectively, which were adapted from the works of Zhu et al. (2005) and Barnes and Scornavacca (2006). Finally, the performance variable was measured using a five-item scale that was adapted from Zhu et al. (2005) and Zhu and Kraemer (2005).

\section{Data Analysis and Results}

To validate the measurements and test the hypotheses we used partial least squares (PLS-SEM). We chose this technique mainly due to our sample limitations. The technique makes minimal demands on sample size and normality, and is therefore especially suitable for testing structural models with relatively small sample sizes (Henseler, Ringle, \& Sinkovics, 2009; Hulland, 1999; Peng \& Lai, 2012). Although PLS estimates both factor loadings and structural paths simultaneously, we followed a two-step approach suggested by Hulland (1999): first we assessed the quality of the measures, namely their reliability and validity; and second we assessed the structural model and tested the hypotheses. In this research we used the SmartPLS software package (Ringle, Wende, \& Will, 2005) to assess both the measurement and structural models.

\section{I Measurement model}

To assess the measurement model, we examined the indicators' reliability, the internal consistency, and 
The influence of the technology-organization-environment framework and strategic orientation on cloud computing use, enterprise mobility, and performance

Table 1

Demographic characteristics of the sample

\begin{tabular}{|c|c|c|c|c|c|}
\hline Characteristic & \multirow{2}{*}{ Freq. } & \multirow{2}{*}{$\%$} & Characteristic & \multirow{2}{*}{ Freq. } & \multirow{2}{*}{$\%$} \\
\hline Number of employees & & & Number of IT staff & & \\
\hline Less than 10 & 23 & $16.8 \%$ & No IT staff & 11 & $8.0 \%$ \\
\hline $10-25$ & 27 & $19.7 \%$ & $1-2$ & 60 & $43.8 \%$ \\
\hline $26-50$ & 19 & $13.9 \%$ & $3-10$ & 34 & $24.8 \%$ \\
\hline $51-100$ & 16 & $11.7 \%$ & $11-50$ & 19 & $13.9 \%$ \\
\hline $101-250$ & 23 & $16.8 \%$ & $>51$ & 13 & $9.5 \%$ \\
\hline$>250$ & 29 & $21.2 \%$ & & & \\
\hline
\end{tabular}

\begin{tabular}{|c|c|c|c|c|c|}
\hline \multicolumn{3}{|c|}{ Sector } & \multicolumn{3}{|c|}{ Respondent's Position } \\
\hline Primary Activities & 2 & $1.5 \%$ & $\begin{array}{l}\text { CEO. President. Manager. } \\
\text { or Owner }\end{array}$ & 35 & $25.5 \%$ \\
\hline Commerce & 20 & $14.6 \%$ & IT Director or Head of IT & 60 & $43.8 \%$ \\
\hline Hospitality and Restaurants & 15 & $10.9 \%$ & Director of other areas & 21 & $15.3 \%$ \\
\hline Manufacturing & 4 & $2.9 \%$ & Others & 21 & $15.3 \%$ \\
\hline Transportation & 5 & $3.6 \%$ & \multicolumn{3}{|c|}{ Respondent's Educational Level } \\
\hline Services & 57 & $41.6 \%$ & Middle school or less & 2 & $1.5 \%$ \\
\hline \multirow[t]{4}{*}{ Other Industries } & 34 & $24.8 \%$ & High school & 21 & $15.3 \%$ \\
\hline & & & $\begin{array}{l}\text { Bachelor's or professional } \\
\text { degree }\end{array}$ & 21 & $15.3 \%$ \\
\hline & & & Licenciate degree & 60 & $43.8 \%$ \\
\hline & & & $\begin{array}{l}\text { Post-graduate or master's } \\
\text { degree }\end{array}$ & 33 & $24.1 \%$ \\
\hline
\end{tabular}

the convergent and discriminant validities. Regarding item reliability, all factor loadings are higher than 0.70 , with only two exceptions (still above 0.65 ), therefore all the items load above the cut-off of 0.5 (Hulland, 1999). Since all the constructs of our model are reflective, this is the only requirement regarding item reliability.

Internal consistency was assessed through the analysis of the Cronbach's alpha $(\alpha)$ and the composite reliability (CR). The constructs of the model present $\alpha$ values ranging from 0.72 to 0.95 and $C R$ values ranging from 0.83 to 0.96 (see Table 2 ). All the values presented are higher than the 0.70 cut-off point suggested in the literature (Fornell \& Larcker, 1981; Henseler et al., 2009) and therefore support the internal consistency of the constructs used.

Convergent validity is also evaluated using two indicators. First, the average variance extracted (AVE) should be above 0.50 for each measure (Bagozzi \& Yi, 1988; Fornell \& Larcker, 1981). Second, the CR needs to show values above 0.80 , as recommended by Koufteros
(1999). All the constructs of our model present AVE values greater than 0.50 (between 0.55 and 0.89 : Table 2), which means the construct can explain more than $50 \%$ of the variance in its indicators. The $\mathrm{CR}$ values also fulfill the requirements, since the lowest value is 0.83 .

To assess discriminant validity, we evaluated three conditions: i) the cross loadings of the indicators, ii) the Fornell-Larcker rule, and iii) the heterotrait-monotrait ratio of correlations (HTMT). The analysis of the loadings and cross loadings of all the 49 indicators shows that each indicator loads better on its theoretical construct than on any other constructs, and therefore supports discriminant validity. The Fornell-Larcker rule is also adhered to, since the square root of the AVE for all the constructs is higher than the correlation of each of those constructs with the other constructs included in the model (see Table 2). This correlation means that the constructs share more variance with their indicators than with the other constructs, therefore reinforcing their discriminant validity (Fornell \& Larcker, 1981). Further, as presented in 
Table 2

\section{Correlation matrix}

\begin{tabular}{|c|c|c|c|c|c|c|c|c|c|c|c|c|}
\hline Construct & $\mathrm{CP}$ & Comp & Conv & EO & ITkw & IO & LoI & OC & EM & Perf & UCC & TiS \\
\hline $\begin{array}{l}\text { Competitive } \\
\text { Pressure (CP) }\end{array}$ & 0.79 & 0.39 & 0.55 & 0.27 & 0.29 & 0.33 & 0.46 & 0.78 & 0.44 & 0.20 & 0.39 & 0.43 \\
\hline $\begin{array}{l}\text { Compatibility } \\
\text { (Comp) }\end{array}$ & 0.35 & 0.93 & 0.75 & 0.47 & 0.62 & 0.48 & 0.04 & 0.53 & 0.75 & 0.31 & 0.72 & 0.56 \\
\hline $\begin{array}{l}\text { Convenience } \\
\text { (Conv) }\end{array}$ & 0.50 & 0.70 & 0.94 & 0.37 & 0.61 & 0.50 & 0.18 & 0.69 & 0.71 & 0.41 & 0.79 & 0.79 \\
\hline $\begin{array}{l}\text { Entrepreneurial } \\
\text { Orientation (EO) }\end{array}$ & 0.25 & 0.44 & 0.35 & 0.81 & 0.54 & 0.74 & 0.19 & 0.54 & 0.68 & 0.60 & 0.52 & 0.34 \\
\hline $\begin{array}{l}\text { IT Know-How } \\
\text { (ITkw) }\end{array}$ & 0.30 & 0.60 & 0.60 & 0.52 & 0.89 & 0.49 & 0.04 & 0.63 & 0.60 & 0.39 & 0.57 & 0.55 \\
\hline $\begin{array}{l}\text { Innovation } \\
\text { Orientation (IO) }\end{array}$ & 0.32 & 0.45 & 0.46 & 0.71 & 0.49 & 0.95 & 0.11 & 0.54 & 0.67 & 0.61 & 0.48 & 0.46 \\
\hline $\begin{array}{l}\text { Lack of } \\
\text { Interoperability } \\
\text { (LoI) }\end{array}$ & 0.34 & -0.02 & 0.15 & 0.17 & -0.01 & 0.10 & 0.91 & 0.18 & 0.17 & 0.17 & 0.06 & 0.22 \\
\hline $\begin{array}{l}\text { Organizational } \\
\text { Confidence (OC) }\end{array}$ & 0.68 & 0.42 & 0.58 & 0.47 & 0.53 & 0.45 & 0.19 & 0.90 & 0.62 & 0.40 & 0.65 & 0.54 \\
\hline $\begin{array}{l}\text { Enterprise } \\
\text { Mobility (EM) }\end{array}$ & 0.35 & 0.61 & 0.58 & 0.57 & 0.52 & 0.55 & 0.10 & 0.46 & 0.74 & 0.58 & 0.86 & 0.67 \\
\hline $\begin{array}{l}\text { Performance } \\
\text { (Perf) }\end{array}$ & 0.20 & 0.30 & 0.38 & 0.58 & 0.38 & 0.58 & 0.16 & 0.35 & 0.48 & 0.92 & 0.47 & 0.51 \\
\hline $\begin{array}{l}\text { Use of Cloud } \\
\text { Computing } \\
\text { (UCC) }\end{array}$ & 0.35 & 0.65 & 0.72 & 0.47 & 0.54 & 0.431 & 0.05 & 0.52 & 0.66 & 0.41 & 0.87 & 0.65 \\
\hline $\begin{array}{l}\text { Trust in Supplier } \\
\text { (TiS) }\end{array}$ & 0.39 & 0.52 & 0.74 & 0.33 & 0.54 & 0.44 & 0.19 & 0.45 & 0.56 & 0.48 & 0.62 & 0.89 \\
\hline $\begin{array}{l}\text { Cronbach's Alpha } \\
(\alpha)\end{array}$ & 0.72 & 0.92 & 0.93 & 0.88 & 0.94 & 0.94 & 0.80 & 0.76 & 0.72 & 0.95 & 0.84 & 0.94 \\
\hline $\begin{array}{l}\text { Composite } \\
\text { Reliability (CR) }\end{array}$ & 0.84 & 0.95 & 0.95 & 0.92 & 0.95 & 0.96 & 0.91 & 0.91 & 0.83 & 0.96 & 0.90 & 0.96 \\
\hline $\begin{array}{l}\text { Average Variance } \\
\text { Extracted (AVE) }\end{array}$ & 0.63 & 0.86 & 0.88 & 0.68 & 0.79 & 0.90 & 0.83 & 0.83 & 0.55 & 0.84 & 0.76 & 0.78 \\
\hline
\end{tabular}

Note. The boldface scores on the diagonal are the square root of the AVE. Below the diagonal are the correlation matrix and above the diagonal are the HTMT values.

Table 2, the maximum HTMT values obtained are below $0.90 / 0.85$, which are the thresholds for constructs that are conceptually similar or distinct (Hair, Hult, Ringle, \& Sarstedt, 2017; Henseler, Ringle, \& Sarstedt, 2015).

Additionally, the variance inflation factor (VIF) values for all the inner models range between 1.198 and 3.574 and are therefore all below the threshold of 5.0 recommended by Hair et al. (2017). These results indicate that multicollinearity is not a problem in the model.

Since the data for this study were gathered using self-reported measures from a cross-sectional survey, common-method bias needs to be considered (Podsakoff, MacKenzie, Jeong-Yeon, \& Podsakoff, 2003; Podsakoff \& Organ, 1986). Therefore, when designing the questionnaire, precautions were taken to limit the potential for common-method bias, as suggested by
Podsakoff et al. (2003) and Podsakoff and Organ (1986). Some examples of these precautions are: i) the respondents were not informed about the conceptual model; ii) the sequence of questions was randomized throughout the questionnaire and does not follow the configuration of the model; iii) the respondents were informed, in both the invitation email and the initial page of the survey, that the answers are anonymous and confidential; iv) they were asked to respond sincerely, emphasizing that there are no correct or incorrect answers; v) the items regarding each construct were organized in sections instead of separate questions; and vi) the description of the scales included not only the description of the extremes (" 1 " and " 7 ") but also the mean neutral answer (“4”).

Moreover, two ex-post procedures were performed to check for common-method bias issues. First, the 
The influence of the technology-organization-environment framework and strategic orientation on cloud computing use, enterprise mobility, and performance

Harman one factor test (Malhotra, Kim, \& Patil, 2006; Podsakoff et al., 2003) was conducted; all the variables in the study were included in an exploratory factor analysis. The results of this process showed a set of 10 factors with eigenvalues above 1.0, which collectively account for $76.88 \%$ of the total variance explained. Also, the first factor only accounts for $37.17 \%$ of the total variance explained. The second procedure implemented was the marker variable test (Lindell \& Whitney, 2001; Malhotra et al., 2006). The questionnaire contained a marker question regarding knowledge about the researchers' university, which is a variable that is theoretically unrelated with the other variables included in the model. This marker variable shows an average correlation of 0.073 . The results of both these procedures indicate that common-method bias is not a problem in our study (Podsakoff et al., 2003; Podsakoff \& Organ, 1986).

\section{$5 \cdot 2$ Structural model}

To test the proposed model and the set of hypotheses, we ran the structural PLS model and reported the variance explained $\left(\mathrm{R}^{2}\right)$ of the endogenous constructs, as well as the significance of the path coefficients (Hair et al., 2017; Hair, Sarstedt, Ringle, \& Mena, 2012; Peng \& Lai, 2012). The path coefficients, the levels of significance of those paths (using the bootstrapping method of sampling with replacement obtained after 5000 runs), and the $\mathrm{R}^{2}$ of the endogenous constructs are shown in Figure 2.

Based on the significance coefficient and the sign of the relationships we were able to validate several research hypotheses, while others were not supported.

Regarding the variables related to the technological context, lack of interoperability shows a weak and nonsignificant relationship with the use of cloud computing ( $\beta=-0.06$, T-value $=0.78 ; p=0.43)$, which does not support H1. On the contrary, the results show that the other two variables included in the technological context, convenience $(\beta=0.34$, T-value $=2.80 ; \mathrm{p}<0.01)$ and compatibility $(\beta=0.26$, T-value $=2.50 ; \mathrm{p}<0.05)$, are positively associated with the use of cloud computing services, which supports both $\mathrm{H} 2$ and $\mathrm{H} 3$. The results for the relationship between the organizational context variables and the use of cloud computing are also divergent. The organizational confidence variable shows a significant and positive relationship $(\beta=0.21$, T-value $=2.08 ; \mathrm{p}<0.05)$, while the IT know-how variable shows a non-significant relationship ( $\beta=0.02$, T-value $=0.23 ; \mathrm{p}=0.82)$. Therefore,
H4 is supported, while H5 is not. None of the variables related with the environmental context obtained statistical significance in their relationship with the use of cloud computing (trust in the supplier: $\beta=0.15, \mathrm{~T}$-value $=1.41$, $\mathrm{p}=0.16$; competitive pressure: $\beta=-0.11, \mathrm{~T}$-value $=1.28$, $\mathrm{p}=0.20$ ). Hence neither H6 nor H7 are supported.

The hypothesized relationships between strategic orientation and enterprise mobility also gained support. Innovation orientation $(\beta=0.20$, T-value $=2.29 ; \mathrm{p}<0.05)$ and entrepreneurial orientation $(\beta=0.21$, T-value $=2.27 ; \mathrm{p}<0.05)$ show positive relationships with enterprise mobility, which supports both $\mathrm{H} 8$ and $\mathrm{H} 9$. On the other hand, the use of cloud computing shows a positive, strong, and significant relationship with enterprise mobility $(\beta=0.49$, T-value $=7.13$; $\mathrm{p}<0.01$ ), which supports H10. Both variables also have positive relationships with organizational performance (use of cloud computing: $\beta=0.19$, T-value $=2.17, p<0.05$; enterprise mobility: $\beta=0.36$, T-value $=3.60, \mathrm{p}<0.01$ ). Hence, H11 and H12 obtained support.

PLS-SEM seeks to maximize the coefficient of determination $\left(\mathrm{R}^{2}\right)$ values of the endogenous latent variables of a specific model (Hair et al., 2017). Although the rules of thumb differ across research disciplines and levels of model complexity, the fields that are related with management and marketing commonly consider $\mathrm{R}^{2}$ values of $0.75,0.50$, and 0.25 as thresholds to classify the coefficients as, respectively, substantial, moderate, and weak (Hair et al., 2017). Our model presents $\mathrm{R}^{2}$ values for the use of cloud computing $\left(R^{2}=0.56\right)$ and for enterprise mobility $\left(R^{2}=0.56\right)$ that can be classified between moderate and substantial, while performance presents a coefficient that can be classified as weak $\left(R^{2}=0.25\right)$.

\section{Discussion and Conclusions}

Although many studies exist regarding the antecedents and determinants of the adoption and use of cloud computing, the number of studies that analyze the effect of cloud computing on organizational performance or on the enterprise mobility of a company is small (e.g. Garrison, Wakefield, \& Kim, 2015; Khayer et al., 2020). The present study contributes to the existing literature by developing and testing an integrative conceptual model regarding some of the antecedents for the use of cloud computing technologies and the effect of that use on enterprise mobility and performance.

We use the TOE framework and confirm several technological and organizational factors as determinants of 


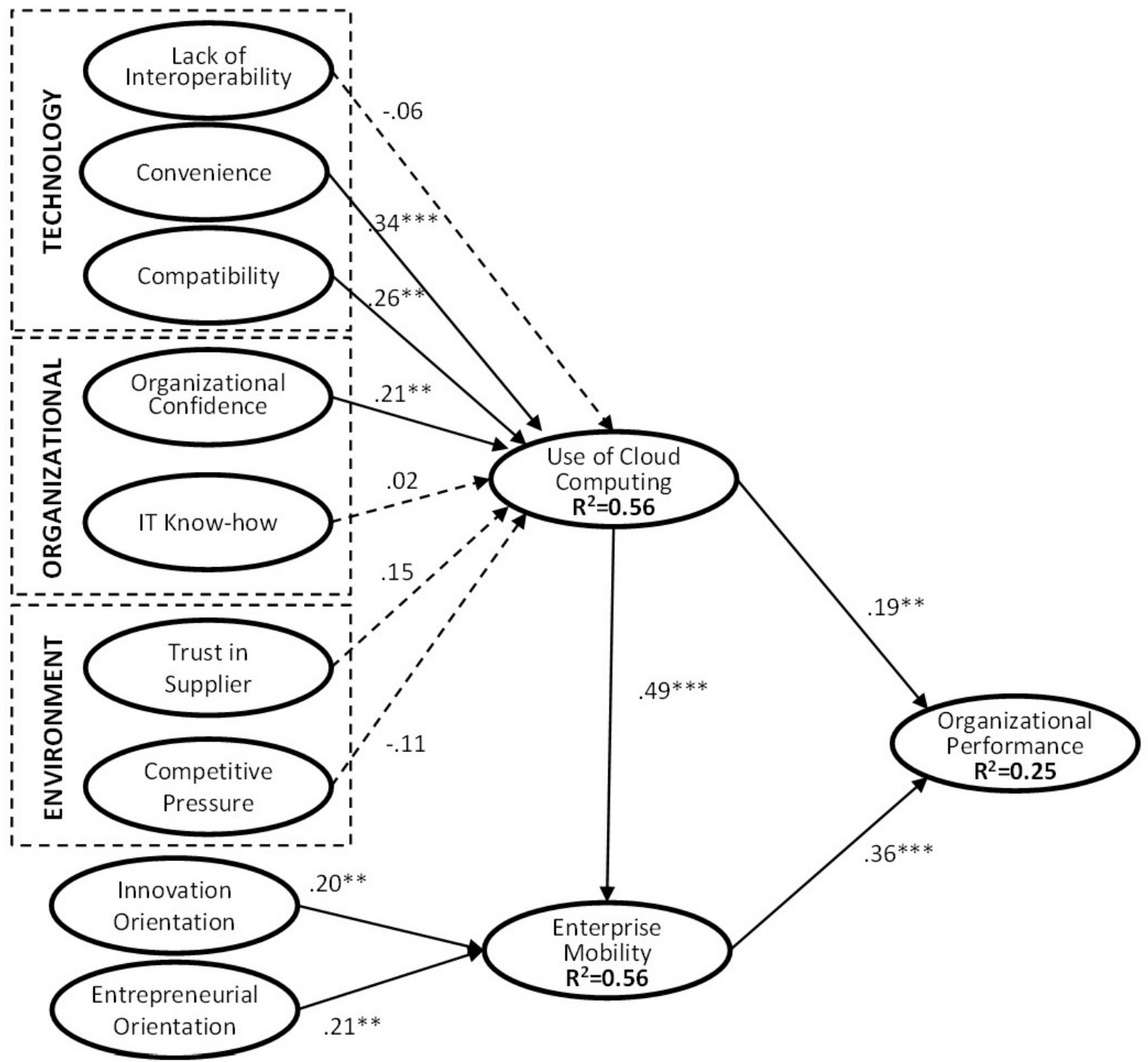

Figure 2. PLS Results in Conceptual Model for Cloud Computing Adoption. Note. ${ }^{\star}$ Significant at $\mathrm{p}<0.1 ;{ }^{* *}$ Significant at $\mathrm{p}<0.05 ;{ }^{* *}$ Significant at $\mathrm{p}<0.01$ (one-tailed)

cloud computing use. Interestingly, we found no support for the idea that the environmental factors in the study were antecedents of the use of this technology. As for the technological context, we confirmed that convenience is a strong determinant of cloud computing use. Based on the rational choice theory (Green, 2002), the adoption of a new technology such as cloud computing follows the organization's interests and preferences. This is in line with previous studies (Gupta et al., 2013; Picoto et al., 2013). Additionally, when deciding to adopt this new technology, organizations also emphasize the need for compatibility with internal organization processes and information systems (Rogers, 2003). This is in line with the results of several studies that also identify this factor as critical for the adoption and use of cloud computing technology (Alshamaila et al., 2013; Lian et al., 2014;
Oliveira et al., 2014; Sharma et al., 2020). We do not confirm the hypothesized relevance of the lack of interoperability as an inhibitor. Therefore, interoperability with the available information and technologies of the organization itself and its business partners does not influence use (Repschlaeger et al., 2013; Teo et al., 2006). Possible explanations for this result are the considerable relevance of compatibility with the organization's internal processes and information systems, as well as the way the questionnaire was designed. Moreover, this variable was the only inhibitor, while all the others were determinants or enhancers of cloud computing use.

Regarding the organizational context, the results show that only organizational confidence is a determinant of cloud computing use. This confirms that the non-existence of organizational anxiety regarding 
The influence of the technology-organization-environment framework and strategic orientation on cloud computing use, enterprise mobility, and performance

a new technology and the belief that the organization possesses the necessary skills and resources to use cloud computing affects its use (Vu et al., 2020). This result also strengthens the literature that highlights that confidence regarding cloud computing technology may positively influence its use (Gupta et al., 2013; Khayer et al., 2020; Low et al., 2011; Priyadarshinee et al., 2017). On the contrary, the expected relevance of IT know-how was not corroborated. Even though the literature emphasizes the need for the necessary skills of IT personnel to enhance the organization's confidence to engage in adopting new technology (Dincă et al., 2019; Lian et al., 2014), in this study we found no support for this factor. Nevertheless, this result may be understood by taking into consideration that the operationalization of the measure focuses mainly on the familiarity and know-how of the organization with the cloud computing technology itself. If the measure had assessed the level of IT know-how in regard to the number of IT experts or the IT budget of the organizations, the result may have been different (Dincă et al., 2019; Garrison et al., 2015; Kauffman et al., 2018).

The environmental factors included in this model were not validated as components that contribute to explaining the use of cloud computing. Even though the literature reinforces the importance of trust in the supplier (Dincă et al., 2019; Gupta et al., 2013) and competitive pressure (Dincă et al., 2019; Lian et al., 2014; Low et al., 2011) as crucial elements of adopting new technologies, they did not achieve statistical significance in this study. One possible explanation may be the fact that we are studying the use of cloud computing and not its adoption, since all the studies that highlight the relevance of these environmental factors use adoption as the dependent variable (Dincă et al., 2019; Low et al., 2011; Wang \& Cheung, 2004). Hence, these environmental factors are more applicable to the adoption decision than to the usage decision after the adoption decision is made.

One interesting finding of this study concerns the relationship between the use of cloud computing and enterprise mobility. This result confirms that the availability of infrastructures, platforms, and applications for cloud computing and universal access support the organization's strategy to implement and use mobile technologies (Nkosi \& Mekuria, 2010). This finding confirms the arguments of Marston et al. (2011) that when organizations use cloud computing they are more likely to convert their business processes to use more mobile applications. Therefore, the use of cloud computing positively contributes to achieving the expected benefits from reorganizing the organization's business model to include mobile business characteristics, and thus to achieving enterprise mobility (Picoto et al., 2013; Stieglitz \& Brockmann, 2012).

A second interesting finding of this study concerns the relevance that the organization's strategic orientations have for increasing enterprise mobility. Both innovational and entrepreneurial orientations show significant relationships with enterprise mobility, which supports their relevance to organizations for adopting new innovations and technologies (Han et al., 1998; Julien \& Raymond, 1994; Wang \& Qualls, 2007; Yu et al., 2018). This research is aligned with the studies that identify entrepreneurial orientation (Lal, 1999; PérezLuño et al., 2011; Putniņš \& Sauka, 2019; Zhai et al., 2018) and innovational orientation (Ali et al., 2017; Chou et al., 2017; Ergün \& Kuşcu, 2013; Hurley \& Hult, 1998; Moon \& Norris, 2005; Wang \& Cheung, 2004) as critical factors for accepting, adopting, and using new technologies and new organizational innovations such as cloud computing. Therefore, these results also confirm the arguments of Moon and Norris (2005) that entrepreneurial-and innovation-oriented organizations are more receptive to new managerial approaches. But even so, this is the first study, as far as we know, to empirically confirm the relevance of these strategic orientations to support the digital transformation of organizations and to enhance enterprise mobility (Ali et al., 2017; Chou et al., 2017; Ergün \& Kuşcu, 2013; Putniņš \& Sauka, 2019; Zhai et al., 2018).

We also found support for the hypothesized relationship between the use of cloud computing and organizational performance. This result confirms the arguments of Marston et al. (2011), Sharma et al. (2020), and $\mathrm{Vu}$ et al. (2020) that organizations that use cloud computing technologies expect to achieve cost efficiency, flexibility, greater access to IT resources, and business agility, which translate into organizational performance. This is also in line with the results of studies that have found a positive relationship between the adoption and use of several IT systems and organizational performance (Chan \& Chong, 2012; Ilmudeen et al., 2019; Khayer et al., 2020).

Further, this study finds that enterprise mobility is positively related to organizational performance. We corroborate the arguments that the transformation of organizations towards mobility has the main objective of achieving higher business value and, therefore, superior performance (Picoto et al., 2013; Stieglitz \& Brockmann, 
2012). This is also in line with one study (Wang et al., 2018) that argues that enterprise mobility has a positive effect on organizations' performance.

This study provides contributions for both academics and practitioners. For academics, it is the first study to combine the TOE framework with strategic orientations as determinants of cloud computing use and enterprise mobility that confirms the relationship between those constructs. In fact, we find that cloud computing use enables the enterprise mobility of a company, by facilitating ubiquitous access to informational resources. Enterprise mobility is an integral part of digital transformation. Interestingly, the strategic orientation constructs of entrepreneurial and innovational orientation are also positively associated with enterprise mobility, highlighting the strategic nature of this concept, which when supported by an adequate technological infrastructure (cloud computing) is able to contribute towards enhancing organizational performance. Finally, our results confirm that higher levels of cloud computing use and enterprise mobility are positively associated with a company's performance. For practitioners, our results show that greater use of cloud computing is related to enhanced performance, which supports the arguments of cloud computing vendors. It also highlights the importance of strategic orientation and enterprise mobility in achieving superior levels of organizational performance.

Nevertheless, this study does have some limitations, such as the size of the sample and the fact that all the organizations included in this research are from a single country. On the other hand, the specific factors included in the conceptual model to test the TOE framework may differ. As we stated previously, we selected these specific factors, but others may be included. Also, organizational performance may be explained by several factors besides the use of cloud computing and enterprise mobility. The reason is that the amount of variance explained by these two variables remains at about $25 \%$. Further research could apply this same model to other countries, as it would be interesting to analyze the effect of environmental and cultural variables on it. The model could also include different types of strategic orientation and consider other determinants of performance, namely as control variables.

\section{References}

Ali, A., Warren, D., \& Mathiassen, L. (2017). Cloudbased business services innovation: A risk management model. International Journal of Information Management, 37(6), 639-649.

Alshamaila, Y., Papagiannidis, S., \& Li, F. (2013). Cloud computing adoption by SMEs in the north east of England. Journal of Enterprise Information Management, 26(3), 250-275.

Amit, R. \& Zott, C. (2001). Value creation in E-business. Strategic Management Journal, 22(6-7), 493-520.

Anderson, J. C. \& Narus, J. A. (1990). A model of distributor firm and manufacturer firm working partnerships. Journal of marketing, 54, 42-58.

Applegate, D. L. (2006). The traveling salesman problem: a computational study. Princeton: Princeton University Press.

Armbrust, M., Fox, A., Griffith, R., Joseph, A. D., Katz, R., Konwinski, A., .. . Zaharia, M. (2010). A view of cloud computing. Communications of the ACM, 53(4), 50-59.

Bagozzi, R., \& Yi, Y. (1988). On the evaluation of structural equation models. Journal of the Academy of Marketing Science, 16(1), 74-94.

Barnes, S. J. (2003). Enterprise mobility: Concept and examples. International Journal of Mobile Communications, 1(4), 341-359.

Barnes, S. J., \& Scornavacca, E. (2006). Wireless applications in New Zealand businesses: A strategic assessment. Journal of Computer Information Systems, 47(1), 46-55.

Beatty, R. C., Shim, J. P., \& Jones, M. C. (2001). Factors influencing corporate web site adoption: A time-based assessment. Information \& Management, 38(6), 337-354.

Behrend, T. S., Wiebe, E. N., London, J. E., \& Johnson, E. C. (2011). Cloud computing adoption and usage in community colleges. Behaviour \& Information Technology, 30(2), 231-240.

Caselli, F., \& Coleman, W. J. (2001). Cross-country technology diffusion: The case of computers. American Economic Review, 91(2), 328-335.

Chan, F. T. S., \& Chong, A. Y. L. (2012). A SEM-neural network approach for understanding determinants 
The influence of the technology-organization-environment framework and strategic orientation on cloud computing use, enterprise mobility, and performance

of interorganizational system standard adoption and performances. Decision Support Systems, 54(1), 621-630.

Chan, Y. E., Huff, S. L., Barclay, D. W., \& Copeland, D. G. (1997). Business strategic orientation, information systems strategic orientation, and strategic alignment. Information Systems Research, 8(2), 125-150.

Chandran, S. P., \& Angepat, M. (2010). Cloud computing: Analysing the risks involved in cloud computing environments. Paper presented at the Proceedings of Natural Sciences and Engineering

Chau, P. Y. K., \& Tam, K. Y. (1997). Factors Affecting the adoption of open systems: An exploratory study. MIS quarterly, 21(1), 1-24.

Chou, C. Y., Chen, J.-S., \& Liu, Y.-P. (2017). Inter-firm relational resources in cloud service adoption and their effect on service innovation. The Service Industries Journal, 37(3-4), 256-276.

Chung, S., Lee, K. Y., \& Kim, K. (2014). Job performance through mobile enterprise systems: The role of organizational agility, location independence, and task characteristics. Information \& Management, 51(6), 605-617.

Connaway, L. S., Dickey, T. J., \& Radford, M. L. (2011). If it is too inconvenient I'm not going after it: Convenience as a critical factor in information-seeking behaviors. Library \& Information Science Research, 33(3), 179-190.

Covin, J. G., \& Slevin, D. P. (1991). A conceptual model of entrepreneurship as firm behavior. Entrepreneurship Theory and Practice, 16(1), 7-25.

Cusumano, M. (2010). Cloud computing and saas as new computing platforms. Communications of the $A C M$, 53(4), 27-29.

Dincă, V. M., Dima, A. M., \& Rozsa, Z. (2019). Determinants of cloud computing adoption by Romanian SMEs in the digital economy. Journal of Business Economics and Management, 20(4), 798-820.

Ergün, H. S., \& Kuşcu, Z. K. (2013). Innovation orientation, market orientation and e-loyalty: Evidence from Turkish e-commerce customers. Procedia - Social and Behavioral Sciences, 99, 509-516.
Fornell, C., \& Larcker, D. F. (1981). Evaluating structural equation models with unobservable variables and measurement error. Journal of Marketing Research, 18(1), 39-50.

Frambach, R. T., \& Schillewaert, N. (2002). Organizational innovation adoption: A multi-level framework of determinants and opportunities for future research. Journal of Business Research, 55(2), 163-176.

Friedman, D., \& Hechter, M. (1988). The contribution of rational choice theory to macrosociological research. Sociological Theory, 6(2), 201-218.

Gangwar, H., Date, H., \& Ramaswamy, R. (2015). Understanding determinants of cloud computing adoption using an integrated TAM-TOE model. Journal of Enterprise Information Management, 28(1), 107-130.

Garrison, G., Wakefield, R. L., \& Kim, S. (2015). The effects of IT capabilities and delivery model on cloud computing success and firm performance for cloud supported processes and operations. International Journal of Information Management, 35(4), 377-393.

Gatignon, H., \& Xuereb, J.-M. (1997). Strategic orientation of the firm and new product performance. Journal of Marketing Research, 34(1), 77-90.

Green, S. L. (2002). Rational choice theory: An overview. Waco, TX: Baylor University..

Gupta, P., Seetharaman, A., \& Raj, J. R. (2013). The usage and adoption of cloud computing by small and medium businesses. International Journal of Information Management, 33(5), 861-874.

Hair, J. F., Hult, G. T. M., Ringle, C. M., \& Sarstedt, M. (2017). A primer on partial least squares structural equations modeling (PLS-SEM) (2nd ed.). Los Angeles: SAGE.

Hair, J. F., Sarstedt, M., Ringle, C., \& Mena, J. (2012). An assessment of the use of partial least squares structural equation modeling in marketing research. Journal of the Academy of Marketing Science, 40(3), 414-433.

Hakala, H. \& Kohtamäki, M. (2010). The interplay between orientations: Entrepreneurial, technology and customer orientations in software companies. Journal of Enterprising Culture, 18, 265-290. 
Hall, B. H. \& Khan, B. (2002). Adoption of new technologies. In D. Jones (Ed.), New Economy Handbook. San Diego, California: Academic Press Inc.

Han, J. K., Kim, N., \& Srivastava, R. K. (1998). Market orientation and organizational performance: Is innovation a missing link? Journal of marketing, 62(4), 30-45.

Henseler, J., Ringle, C. M., \& Sarstedt, M. (2015). A new criterion for assessing discriminant validity in variancebased structural equation modeling. Journal of the Academy of Marketing Science, 43(1), 115-135.

Henseler, J., Ringle, C. M., \& Sinkovics, R. R. (2009). The use of partial least squares path modeling in international marketing. Advances in International Marketing, 20, 277-319.

Hess, T., Matt, C., Benlian, A., \& Wiesböck, F. (2016). Options for formulating a digital transformation strategy. MIS Quarterly Executive, 15(2), 123-139.

Hulland, J. (1999). Use of partial least squares (PLS) in strategic management research: A review of four recent studies. Strategic Management Journal, 20(2), 195-204.

Hurley, R. F., \& Hult, G. T. M. (1998). Innovation, market orientation, and organizational learning: An integration and empirical examination. Journal of marketing, 62(3), 42-54.

Ilmudeen, A., Bao, Y., \& Alharbi, I. M. (2019). How does business-IT strategic alignment dimension impact on organizational performance measures. Journal of Enterprise Information Management, 32(3), 457-476.

Iyer, B., \& Henderson, J. C. (2010). Preparing for the future: Understanding the seven capabilities of cloud computing. MIS Quarterly Executive, 9(2), 117-131.

Jones, R., \& Rowley, J. (2011). Entrepreneurial marketing in small businesses: A conceptual exploration. 29(1), 25-36.

Julien, P.-A., \& Raymond, L. (1994). Factors of new technology adoption in the retail sector. Entrepreneurship Theory and Practice, 18(4), 79-90.

Kauffman, R. J., Ma, D., \& Yu, M. (2018). A metrics suite of cloud computing adoption readiness. Electronic Markets, 28(1), 11-37.
Khayer, A., Talukder, M. S., Bao, Y., \& Hossain, M. N. (2020). Cloud computing adoption and its impact on SMEs' performance for cloud supported operations: A dual-stage analytical approach. Technology in Society, 60, 101225 .

Koufteros, X. A. (1999). Testing a model of pull production: A paradigm for manufacturing research using structural equation modeling. Journal of Operations Management, 17(4), 467-488.

Lal, K. (1999). Determinants of the adoption of information technology: A case study of electrical and electronic goods manufacturing firms in India. Research Policy, 28(7), 667-680.

Lian, J. W., Yen, D. C., \& Wang, Y. T. (2014). An exploratory study to understand the critical factors affecting the decision to adopt cloud computing in Taiwan hospital. International Journal of Information Management, 34(1), 28-36.

Lin, A., \& Chen, N. C. (2012). Cloud computing as an innovation: Percepetion, attitude, and adoption. International Journal of Information Management, 32(6), 533-540.

Lin, H.-F., \& Lin, S.-M. (2008). Determinants of e-business diffusion: A test of the technology diffusion perspective. Technovation, 28(3), 135-145.

Lindell, M. K., \& Whitney, D. J. (2001). Accounting for common method variance in cross-sectional research designs. Journal of Applied Psychology, 86(1), 114-121.

Low, C. Y., Chen, Y. H., \& Wu, M. C. (2011). Understanding the determinants of cloud computing adoption. Industrial management \& data systems, 111(7), 1006-1023.

Lumpkin, G. T., \& Dess, G. G. (1996). Clarifying the entrepreneurial orientation construct and linking it to performance. Academy of Management Review, 21(1), 135-172.

Lumpkin, G. T., \& Dess, G. G. (2001). Linking two dimensions of entrepreneurial orientation to firm performance: The moderating role of environment and industry life cycle. Journal of Business Venturing, 16(5), 429-451. 
The influence of the technology-organization-environment framework and strategic orientation on cloud computing use, enterprise mobility, and performance

Malhotra, N. K., Kim, S. S., \& Patil, A. (2006). Common method variance in IS research: A comparison of alternative approaches and a reanalysis of past research. Management Science, 52(12), 1865-1883.

Marston, S., Li, Z., Bandyopadhyay, S., Zhang, J., \& Ghalsasi, A. (2011). Cloud computing - The business perspective. Decision Support Systems, 51(1), 176-189.

Miller, D., \& Friesen, P. H. (1983). Strategy-making and environment: The third link. strategic management journal, 4(3), 221-235.

Moon, M. J., \& Norris, D. F. (2005). Does managerial orientation matter? The adoption of reinventing government and e-government at the municipal level. Information Systems Journal, 15(1), 43-60.

Narver, J. C., \& Slater, S. F. (1990). The effect of a market orientation on business profitability. Journal of marketing, 54(4), 20-35.

Nkhoma, M. Z., \& Dang, D. (2013). Contributing factors of cloud computing adoption: A technology-organisationenvironment framework approach. International Journal of Information Systems Engeneering, 1(1), 38-49.

Nkosi, M. T., \& Mekuria, F. (2010). Cloud computing for enhanced mobile health applications. Paper presented at the Cloud Computing Technology and Science (CloudCom), 2010 IEEE Second International Conference on Cloud Computing, Indianapolis. DOI: 10.1109/ CloudCom.2010.31

Nonaka, I., Toyama, R., \& Konno, N. (2000). SECI, Ba and leadership: A unified model of dynamic knowledge creation. Long Range Planning, 33(1), 5-34.

Oliveira, T., Thomas, M., \& Espadanal, M. (2014). Assessing the determinants of cloud computing adoption: An analysis of the manufacturing and services sectors. Information \& Management, 51(5), 497-510.

Patel, R. (2014). Enterprise Mobility Strategy \& Solutions. New Delhi: Partridge.

Peng, D. X., \& Lai, F. (2012). Using partial least squares in operations management research: A practical guideline and summary of past research. Journal of Operations Management, 30(6), 467-480.
Pérez-Luño, A., Wiklund, J., \& Cabrera, R. V. (2011). The dual nature of innovative activity: How entrepreneurial orientation influences innovation generation and adoption. Journal of Business Venturing, 26(5), 555-571.

Picoto, W. N., Bélanger, F., \& Palma-dos-Reis, A. (2013). M-Business organizational benefits and value: A qualitative study. Journal of Organizational Computing and Electronic Commerce, 23(4), 287-324.

Picoto, W. N., Bélanger, F., \& Palma-Dos-Reis, A. (2014). An organizational perspective on m-business: Usage factors and value determination. European Journal of Information Systems, 23(5), 571-592.

Podsakoff, P. M., MacKenzie, S. B., Jeong-Yeon, L., \& Podsakoff, N. P. (2003). Common method biases in behavioral research: A critical review of the literature and recommended remedies. Journal of Applied Psychology, 88(5), 879-903.

Podsakoff, P. M., \& Organ, D. W. (1986). Self-Reports in organizational research: Problems and prospects. Journal of Management, 12(4), 531-544.

Priyadarshinee, P., Raut, R. D., Jha, M. K., \& Gardas, B. B. (2017). Understanding and predicting the determinants of cloud computing adoption: A two staged hybrid SEM - Neural networks approach. Computers in Human Behavior, 76, 341-362.

Putninšs, T. J., \& Sauka, A. (2019). Why does entrepreneurial orientation affect company performance? Strategic Entrepreneurship Journal, early view, 1-25.

Repschlaeger, J., Erek, K., \& Zarnekow, R. (2013). Cloud computing adoption: An empirical study of customer preferences among start-up companies. Electronic Markets, 23(2), 115-148.

Ringle, C. M., Wende, S., \& Will, A. (2005). SmartPLS Version 2.0M3. Hamburg, Germany. (Version www. smartpls.de)

Rogers, E. M. (2003). Diffusion of Innovations (5th ed.). New York: Free Press.

Salavou, H., Baltas, G., \& Lioukas, S. (2004). Organisational innovation in SMEs: The importance of strategic orientation 
and competitive structure. European journal of marketing, 38(9-10), 1091-1112.

Senyo, P. K., Addae, E., \& Boateng, R. (2018). Cloud computing research: A review of research themes, frameworks, methods and future research directions. International Journal of Information Management, 38(1), 128-139.

Senyo, P. K., Effah, J., \& Addae, E. (2016). Preliminary insight into cloud computing adoption in a developing country. Journal of Enterprise Information Management, 29, 505-524.

Serrano, A., Caldeira, M., \& Guerreiro, A. (2004). Gestão de Sistemas e Tecnologias de Informação. Lisbon: FCA Editora de Informática.

Sharma, M., Gupta, R., \& Acharya, P. (2020). Prioritizing the critical factors of cloud computing adoption using multi-criteria decision-making techniques. Global Business Review, 21(1), 142-161.

Shen, Y.-C., Huang, C.-Y., Chu, C.-H., \& Hsu, C.-T. (2010). A benefit-cost perspective of the consumer adoption of the mobile banking system. Behaviour \& Information Technology, 29(5), 497-511.

Siguaw, J. A., Simpson, P. M., \& Enz, C. A. (2006). Conceptualizing innovation orientation: A framework for study and integration of innovation research. Journal of Product Innovation Management, 23(6), 556-574.

Sørensen, C. (2011). Enterprise mobility: Tiny technology with global impact on work. London: Springer.

Stieglitz, S., \& Brockmann, T. (2012). Increasing organizational performance by transforming into a mobile enterprise. MIS Quarterly Executive, 11(4), 189-204.

Swanson, E. B. (1994). Information Systems innovation among organizations. Management Science, 40(9), 10691092.

Synergy Research Group [S. Moss]. (2019). Synergy: Data center hardware, software spending hits $\$ 150$ billion in 2018 [online]. Retrieved from https://www. datacenterdynamics.com/en/news/synergy-data-centerhardware-software-spending-2018-hit-150-billion/
Tam, C., \& Oliveira, T. (2017). Understanding mobile banking individual performance. Internet Research, 27(3), 538-562.

Teo, T. S. H., Ranganathan, C., \& Dhaliwal, J. (2006). Key dimensions of inhibitors for the deployment of webbased business-to-business electronic commerce. IEEE Transactions on Engineering Management, 53(3), 395-411.

Tornatzky, L. G., \& Fleischer, M. (1990). The processes of technological innovation. Lexington, Mass.: Lexington Books.

Tornatzky, L. G., \& Klein, K. J. (1982). Innovation characteristics and innovation adoption implementation: A meta-analysis of findings. IEEE Transactions on Engineering Management, 29(1), 28-45.

Vu, K., Hartley, K., \& Kankanhalli, A. (2020). Predictors of cloud computing adoption: A cross-country study. Telematics and Informatics, 52, 101426.

Wang, C., Ren, K., Wang, J., \& Ieee. (2011). Secure and Practical Outsourcing of Linear Programming in Cloud Computing. Paper presented at the 2011 Proceedings IEEE Infocom, Shanghai.

Wang, C. L. (2008). Entrepreneurial orientation, learning orientation, and firm performance. Entrepreneurship: Theory \& Practice, 32(4), 635-657.

Wang, S., \& Cheung, W. (2004). E-business adoption by travel agencies: Prime candidates for mobile e-business. International Journal of Electronic Commerce, 8(3), 43-63.

Wang, Y.-M., Wang, Y.-S., \& Yang, Y.-F. (2010). Understanding the determinants of RFID adoption in the manufacturing industry. Technological Forecasting and Social Change, 77(5), 803-815.

Wang, Y., Chen, Y., Zhu, T., \& Lin, D. (2018). Unpacking the organizational impacts of enterprise mobility using the repertory grid technique. Internet Research, 28(1), 143-168.

Wang, Y., \& Qualls, W. (2007). Towards a theoretical model of technology adoption in hospitality organizations. International Journal of Hospitality Management, 26(3), 560-573. 
Wiklund, J., \& Shepherd, D. (2005). Entrepreneurial orientation and small business performance: a configurational approach. Journal of Business Venturing, 20(1), 71-91.

Yu, Y., Li, M., Li, X., Zhao, J. L., \& Zhao, D. (2018). Effects of entrepreneurship and IT fashion on SMEs' transformation toward cloud service through mediation of trust. Information \& Management, 55(2), 245-257.

Zhai, Y.-M., Sun, W.-Q., Tsai, S.-B., Wang, Z., Zhao, Y., \& Chen, Q. (2018). An empirical study on entrepreneurial orientation, absorptive capacity, and SMEs' innovation performance: A sustainable perspective. Sustainability, 10(2), 314.

Zhang, L.-J. (2012). Editorial: Big services era: Global trends of cloud computing and big data. IEEE Transactions on Services Computing, 5(4), 467-468.
Zhou, K. Z., Gao, G. Y., Yang, Z., \& Zhou, N. (2005a). Developing strategic orientation in China: Antecedents and consequences of market and innovation orientations. Journal of Business Research, 58(8), 1049-1058.

Zhou, K. Z., Yim, C. K., \& Tse, D. K. (2005b). The effects of strategic orientations on technology- and market-based breakthrough innovations. Journal of marketing, 69(2), 42-60.

Zhu, K., Dong, S., Xu, S. X., \& Kraemer, K. L. (2006). Innovation diffusion in global contexts: Determinants of post-adoption digital transformation of European companies. European Journal of Information System, 15(6), 601-616.

Zhu, K., \& Kraemer, K. L. (2005). Post-adoption variations in usage and value of e-business by organizations: Crosscountry evidence from the retail industry. Information Systems Research, 16(1), 61-84. 


\section{APPENDIX}

\section{MEASUREMENT ITEMS AND VALIDITY ASSESSMENT}

\begin{tabular}{|c|c|}
\hline CONSTRUCT / indicator & Loadings \\
\hline \multicolumn{2}{|l|}{ LACK OF INTEROPERABILITY $\alpha=0.89 / \mathrm{CR}=0.83 / \mathrm{AVE}=0.62$} \\
\hline Lack of interoperability between the new cloud computing applications and the previously existing systems. & 0.903 \\
\hline Difficulties regarding the integration of cloud computing applications into the existing applications and systems. ${ }^{*}$ & - \\
\hline Lack of interoperability between the new cloud computing applications and the business partners (suppliers, customers, etc.). & 0.919 \\
\hline \multicolumn{2}{|l|}{ CONVENIENCE $\alpha=0.93 / \mathrm{CR}=0.95 / \mathrm{AVE}=0.87$} \\
\hline My organization values the convenience of cloud computing. & 0.909 \\
\hline Cloud computing services are an efficient way to manage time in my organization. & 0.949 \\
\hline The convenience of the cloud computing services that my organization uses can help to avoid some mistakes. & 0.947 \\
\hline \multicolumn{2}{|l|}{ COMPATIBILITY $\alpha=0.92 / \mathrm{CR}=0.95 / \mathrm{AVE}=0.86$} \\
\hline Cloud computing is compatible with the existing business processes in my organization. & 0.932 \\
\hline Cloud computing is compatible with the organizational culture of my organization. & 0.922 \\
\hline Cloud computing is compatible with the existing information infrastructure in my organization. & 0.932 \\
\hline \multicolumn{2}{|l|}{ ORGANIZATIONAL CONFIDENCE $\alpha=0.76 / \mathrm{CR}=0.86 / \mathrm{AVE}=0.67$} \\
\hline My organization is confident in being a pioneering user of cloud computing services. & 0.898 \\
\hline The workers in my organization feel that learning to use new cloud computing services is exciting. & 0.874 \\
\hline The workers in my organization are not worried about irreparable mistakes they can commit when $c$ & 0.665 \\
\hline
\end{tabular}
services.

The workers in my organization are worried about losing important information if they access to wrong files/services. *

\begin{tabular}{|c|c|}
\hline IT KNOW-HOW $\alpha=0.94 / \mathrm{CR}=0.95 / \mathrm{AVE}=0.79$ & \\
\hline My organization is familiar with cloud computing services. & 0.902 \\
\hline My organization knows a lot about cloud computing services. & 0.913 \\
\hline My organization is familiar with the characteristics of cloud computing services that are relevant to the business. & 0.915 \\
\hline My organization usually reads information brochures about the supplier of cloud computing services. & 0.858 \\
\hline My organization usually reads information brochures about several suppliers of cloud computing services. & 0.851 \\
\hline TRUST IN SUPPLIER $\alpha=0.94 / \mathrm{CR}=0.96 / \mathrm{AVE}=0.78$ & \\
\hline My organization thinks that the supplier of cloud computing services is trustworthy. & 0.869 \\
\hline $\begin{array}{l}\text { My organization thinks that the supplier of cloud computing services will do everything in their capacity to protect the } \\
\text { subscribers' rights. }\end{array}$ & 0.921 \\
\hline $\begin{array}{l}\text { My organization thinks that the supplier of cloud computing services will do everything to guarantee the business } \\
\text { operations of their users. }\end{array}$ & 0.937 \\
\hline $\begin{array}{l}\text { My organization thinks that the supplier of cloud computing services is capable of overcoming all kinds of technical } \\
\text { difficulties. }\end{array}$ & 0.857 \\
\hline My organization thinks that the supplier of cloud computing services will do everything to help users if problems arise. & 0.859 \\
\hline My organization believes that certain technical procedures exist to protect personal/business information & 0.862 \\
\hline COMPETITIVE PRESSURE $\alpha=0.72 / \mathrm{CR}=0.84 / \mathrm{AVE}=0.63$ & \\
\hline My organization had to suffer from competitive pressure in order to adopt cloud computing. & 0.702 \\
\hline My organization would have been at a competitive disadvantage if it had not adopted cloud computing. & 0.846 \\
\hline ITC plays a major role in the competitiveness of the industry. & 0.826 \\
\hline ENTREPRENEURIAL ORIENTATION $\alpha=0.88 / \mathrm{CR}=0.92 / \mathrm{AVE}=0.68$ & \\
\hline Concerning competitors, my organization typically initiates actions which compet & 0.783 \\
\hline Concerning competitors, my organization is very often the first business to introduce new products/ser & 0.853 \\
\hline
\end{tabular}

administrative techniques, operating technologies, etc.

In general, the top managers of my organization have a strong tendency to be ahead of others in introducing novel ideas or products.

In general, the top managers of my organization favor a strong emphasis on $\mathrm{R} \& \mathrm{D}$, technological leadership, and innovations.

My organization introduced many new lines of products/services in the past 3 years.

Changes in the organization's product or service lines have usually been quite dramatic.

There is a strong proclivity for high risk projects (with chances of very high returns).

Note. ${ }^{\star}$ - This item was deleted during the scale purification process. 
The influence of the technology-organization-environment framework and strategic orientation on cloud computing use, enterprise mobility, and performance

\section{CONSTRUCT / indicator}

Loadings

When confronted with decisions involving uncertainty, my firm typically adopts a bold posture in order to maximize the 0.781 probability of exploiting opportunities.

\section{INNOVATION ORIENTATION $\alpha=0.94 / \mathrm{CR}=0.96 / \mathrm{AVE}=0.90$}

Our company pays close attention to innovation.

Our company emphasizes the need for innovation for development.

0.964

Our company promotes the need for development and the utilization of new resources.

0.946

\section{ENTERPRISE MOBILITY $\alpha=0.72 / \mathrm{CR}=0.83 / \mathrm{AVE}=0.55$}

The existing mobile applications in my organization are electronically integrated with my database and information

systems.

The workers in my organization regularly need to work in different places and "on the move".

Informational delays can significantly affect the performance of some tasks.

The performance of some tasks can be negatively affected if they need to be executed at another time or in another place.

USE OF CLOUD COMPUTING $\alpha=0.83 / \mathrm{CR}=0.90 / \mathrm{AVE}=0.76$

Cloud computing supports the workers of my organization in their tasks outside the office.

Cloud computing supports the immediate work of the employees, when necessary.

The internal processes of my organization are conducted through the platforms provided by cloud computing.

Helps to increase sales.

Helps to reduce costs.

Helps to reduce administrative work.

0.942

Helps to collect and analyze data faster.

0.909

Positively affects the value of my organization's brands and partnerships.

0.929

Note. ${ }^{*}$ - This item was deleted during the scale purification process. 


\section{Copyrights:}

RBGN owns the copyrights of this published content.

\section{Plagiarism analysis:}

RBGN performs plagiarism analysis on all its articles at the time of submission and after approval of the manuscript using the iThenticate tool.

\section{Authors:}

1. Winnie Ng Picoto, PhD, University of Lisbon, Lisbon, Portugal.

E-mail: w.picoto@iseg.ulisboa.pt

2. Nuno Fernandes Crespo, PhD, University of Lisbon, Lisbon, Portugal.

E-mail: ncrespo@iseg.ulisboa.pt

3. Filipa Kahn Carvalho, MSc, University of Lisbon, Lisbon, Portugal.

E-mail: filipa.kahn@hotmail.com

\section{Authors' Contributions:}

Winnie Ng Picoto: Definition of research problem; Development of hypotheses or research questions (empirical studies); Development of theoretical propositions (theoretical work); Definition of methodological procedures; Data Collection; Literature review; Statistical analysis; Analysis and interpretation of data; Critical revision of the manuscript; Manuscript writing.

Nuno Fernandes Crespo: Definition of research problem; Development of hypotheses or research questions (empirical studies); Development of theoretical propositions (theoretical work); Definition of methodological procedures; Data Collection; Literature review; Statistical analysis; Analysis and interpretation of data; Critical revision of the manuscript; Manuscript writing.

Filipa Kahn Carvalho: Definition of research problem; Development of hypotheses or research questions (empirical studies); Development of theoretical propositions (theoretical work); Definition of methodological procedures; Data Collection; Literature review; Statistical analysis; Analysis and interpretation of data. 